$14^{\text {th }}$ Conf. Agric. Develop. Res., Fac. of Agric., Ain Shams

Univ., March, 2019, Cairo, Egypt

Special Issue, 27(1), 115 - 121, 2019

Website: http://strategy-plan.asu.edu.eg/AUJASCI/

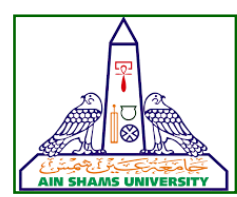

115

\title{
ELECTRONIC VISION AND USES IN AUTOMATIC HANDLING OF AGRICULTURAL MATERIALS
}

\author{
Al-Shaymaa M.R. Abdel-Zaher, Awady, M.N. and El Sahhar, E.S. \\ Agric. Engineering Dept., Fac. of Agric., Ain Shams Univ., P.O. Box 68 Hadyek Shoubra 11241, \\ Cairo, Egypt
}

*Corresponding author: alshaymaamoselhy@agr.asu.edu.eg

Received 3 February, 2019, Accepted 17 February, 2019

\begin{abstract}
Sorting machines of fruits are mostly used in the industries. The process of sorting started by detecting the color of the fruits to indicate its classification based on the color of the fruit. In this work, a fruit sorting machine has been designed and built for small scale industries needing low cost compared to those now being used, which are expensive. This quest focuses on sorting the different types of fruits such as apples, tomatoes, and navel orange which are green and red. The fruits are put on a small belt and then entered through a box with a controlled lighting Red- Green- Blue color sensor. The controlled lighting is in a closed space with a servo motor which rotates 130 degree and returns to zero position. Attached to it, a gate pushes the fruit to the line of correct color and RGB color sensor to make scanning, integrated with Red and non-Red (Green) Light Emitting Diode (RGB LED), to detect the color of the fruit. Study also includes productivity, efficiency and costs were determined.
\end{abstract}

Results revealed the following

- The productivity is arranged from low to high as follows: tomatoes (27.3: $61.2 \mathrm{~kg} / \mathrm{h}$ ), apples (34.1: $76.5 \mathrm{~kg} / \mathrm{h}$ ), and navel orange (68.1: $153 \mathrm{~kg} / \mathrm{h})$.

- The efficiency of sorting was as follows: tomatoes was $96 \%$ at the lowest belt speed and increased to $100 \%$ at the mean belt speed $0.8 \mathrm{~m} / \mathrm{s}$ then decreased to $94 \%$ at the highest speed, apples was $95 \%$ at the lowest belt speed and increased to $100 \%$ at the mean belt speed $0.8 \mathrm{~m} / \mathrm{s}$ then decreased to
$91.25 \%$ at the highest speed, and navel orange was $95 \%$ at the lowest belt speed and increased to $100 \%$ at the mean belt speed $0.8 \mathrm{~m} / \mathrm{s}$ then decreased to $80 \%$ at the highest speed.

- The most suitable belt speed was $0.8 \mathrm{~m} / \mathrm{s}$ with very small delay time of servo motor which gives the highest efficiency of sorting within free flowing conditions.

The sorting process cost by using the developed machine was less than the manual process in case of navel orange, tomatoes and apples. Using the developed sorting machine reduced the cost of fruits sorting to $1: 2.23$ as compared with manual method in navel orange, and to $1: 1.12$ for apples, but it was more expensive sorting tomatoes by the developed machine compared with manual sorting of $12 \%$.

Keywords: Electronic vision, Automatic handling of fruits

\section{INTRODUCTION}

A wide range of technologies has been developed for sorting according to color, density, diameter, shape and weight. Automation is getting important in the sorting process, because computers or machines work quickly and effectively. Thus machines also sort fruits according to grades without mistakes. This automation system, which consists of mechanical structure with electronics, is designed to be used in small agricultural industries. Usually, a lot of human errors occur during the process of fruit sorting. Usually operators can 
work 7-8 hours per day. Working more hours can make workers lose their focus. Automation systems are designed to solve this problem and produce efficient and high productivities.

Shen and Hassan (2015) pointed out that in order to create a smart robot that can recognize color ball and place them at the correct location, research in wave length is needed. The real contribution of this system is that it is able to save time to sort the color hence making this Arduinopowered color recognizing and sorting robot more efficient than the existing system. Upon finishing of this project, a robot that has capability to recognize color of the ball and sorts them according to their color is successfully created.

\section{MATERIAL AND METHODS}

\section{Materials}

\section{1) Sorting machine description}

The design of the proposed sorting model is shown in Fig. (1) and Fig. (2). The system of sorting has two main parts: the first is a conveyor belt constructed of fabric and connecting two steel pullies. The belt consists of two lanes: one for redfruits and another for non-red fruits and the second is an "Arduino UNO" flip - Hop diverting board set up with Red- Green- Blue color sensing and a servo motor to move a gate with the sorting line of color grade.

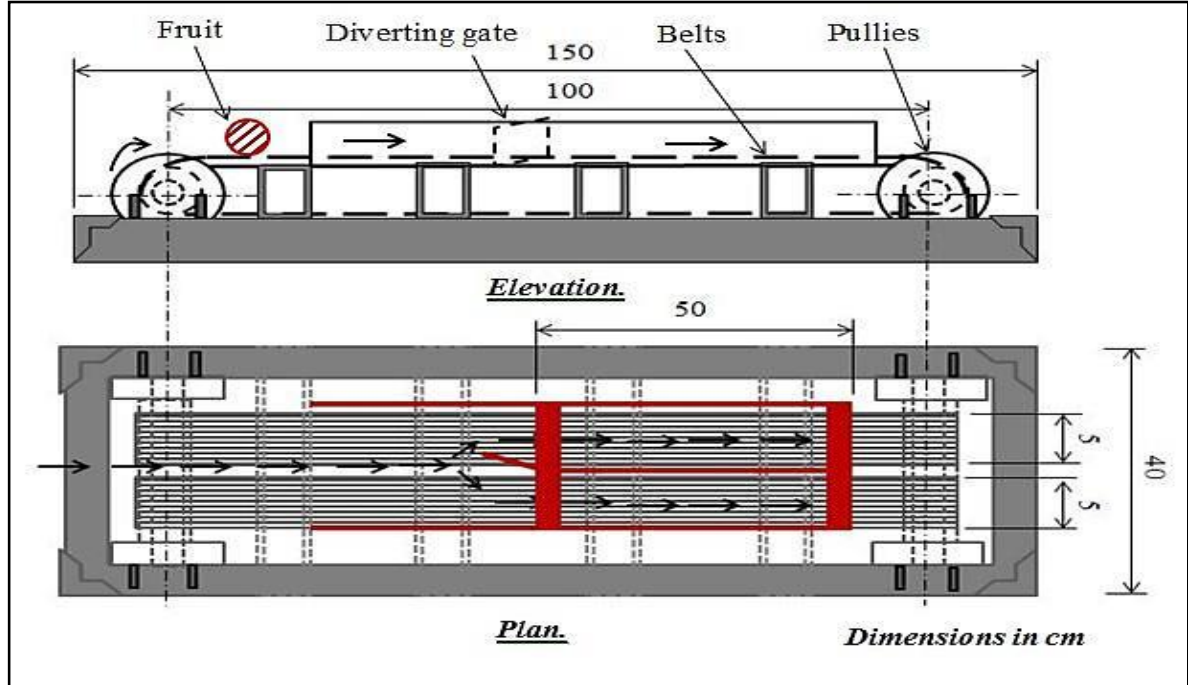

Fig. 1. Layout of the whole system.

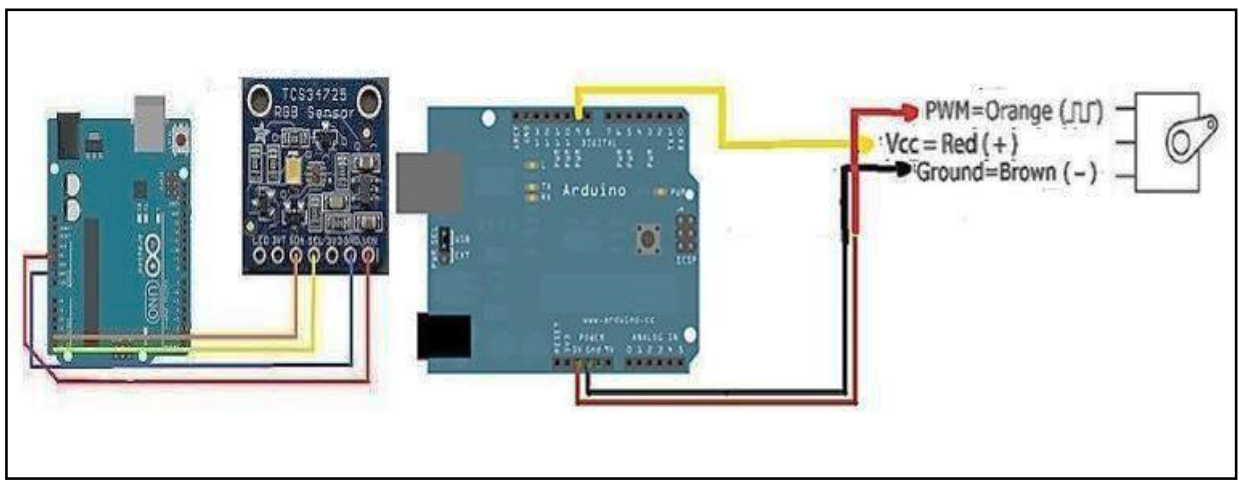

Fig. 2. "Arduino" connecting with servo motor and sensor. 
The motion source through an electric adaptor operates a DC electric motor type DME38850G102 on 24 Volt, 120 Watt, made in Taiwan.

\section{2) Source of motion}

An electrical DC motor, type DME 38S50G-102 was used with adaptor to reduce 220 Volt $A C$ to suit operating voltage of the motor: to variable voltages of $9,12,15,18$, and $24 \mathrm{~V}$. When the voltage increases, the speed of motor increases and consequently the belt speed.

\section{3) The conveyor belt}

The material of the belt chosen was fabric forming two lines of sorting with length of $100 \mathrm{~cm}$ and $5 \mathrm{~cm}$ width each lane. They take power and motion from the same motor.

\section{4) The sorting part}

The separation of the objects (fruits) depends on a color sensor RGB TCS34725 on the ARDUINO UNO board.

\section{5) The separation part (SP)}

The SP is a gate with servo motor to detect the color and sort the object to the left hand side line if red color or to the right hand side line if non red color.

\section{6) The servo motor}

The servo motor type was standard "micro servo SG90" to move the gate which makes the direction of color sorting as red or non-red. The position of the servo motor is set by the length of a pulse, can rotate approximately 180 degrees (90 in each direction). Position "0" (1.5 mms pulse) is middle, "90" ( 2mms pulse) is all the way to the right, "-90" ( $1 \mathrm{mms}$ pulse) is all the way to the left.

\section{Methods and calculations}

\section{1) Rate of performance}

Rate was compared for two conditions, as follows:

\section{A) Hand labor productivity}

Sorting rate was measured under the following conditions
- Total mass of fruits $=20 \mathrm{~kg}$,

- $\quad$ The belt / line length $=1.5 \mathrm{~m}$;

- Number of laborers $=1$ laborer / line.

\section{B) Automatic system productivity}

Productivity was measured to evaluate productivity by sorting machine under these conditions:

- Total mass of fruits $=20 \mathrm{~kg}$

- The belt / line length $=1 \mathrm{~m}$;

- The sorting part; with RGB color sensor

Automatic sorting rate $=$ mass of fruits $/$ sorting time

Eq. 1.

This experiment was to calculate the total time for the sorting system by the RGB color sensor.

2) Dimensional analysis of system productivity

Factors which affect productivity of sorting system can be as follows:

\begin{tabular}{|c|l|c|}
\hline Symbol & \multicolumn{1}{|c|}{ Definition } & Dims \\
\hline $\mathrm{P}_{\mathrm{r}}$ & $\begin{array}{l}\text { Color sorting system productivity } \\
\text { (ton/h) }\end{array}$ & $\mathrm{M} / \mathrm{T}$ \\
\hline $\mathrm{v}$ & Belt speed $(\mathrm{m} / \mathrm{s})$ & $\mathrm{L} / \mathrm{T}$ \\
\hline $\mathrm{T}$ & Delay time of servomotor (s) & $\mathrm{T}$ \\
\hline$\lambda$ & $\begin{array}{l}\text { Red component ratio to the RGB } \\
\text { white-base } \\
\text { "73\% for red apples, 38\% for } \\
\text { green apples, 100\% for navel } \\
\text { oranges, 100\% for tomatoes" }\end{array}$ & \\
\hline $\boldsymbol{\rho}$ & Density of fruits $\left(\mathrm{kg} / \mathrm{m}^{3}\right)$ & $\mathrm{M} / \mathrm{L3}$ \\
\hline $\mathrm{m}$ & Fruit mass $(\mathrm{kg})$ & $\mathrm{M}$ \\
\hline
\end{tabular}

Factors affecting productivity of machine are mainly as follows:

$$
f\left(P_{r}, v, T, \lambda, \rho, m\right)=0
$$

$\therefore \pi$ "No. of groups" = No. of variables - No. of dimensions

$\therefore \pi=6-3=3 \pi$ 's

Factors are grouped as follows: (as suggested by Prof. Dr. Awady, 2018)

$$
\begin{array}{lll}
\text { Group (1): } & * \quad \pi 1=\frac{P_{r} T}{m} \\
\text { Group (2): } & * \pi 2=\frac{\mathrm{v} T \rho^{1 / 3}}{m^{1 / 3}} \\
\text { Group (3): } & \therefore \quad \pi 3=\lambda
\end{array}
$$

Groups which affect on productivity of sorting machine can be arranged as follows:

$$
\frac{P_{r} T}{m}=f\left\{\frac{\mathrm{v} T \rho^{1 / 3}}{m^{1 / 3}}, \lambda\right\}
$$




\section{3) Cost of sorting}

The cost per hour "L.E./h" was determined using the following equation according to Awady, (1978):

where:

C $=$ Hourly cost in L.E.

$\mathrm{P}=$ Capital investment in L.E.

$\mathrm{h}=$ Yearly operating hours.

$\mathrm{e}=$ Life expectancy of the machine in years.

$\mathrm{i}=$ Interest rate.

$\mathrm{t}=$ Taxes and overheads ratio.

$r=$ Maintenances and repairs ratio of the total investment.

$\mathrm{P}_{\mathrm{w}}=$ Horsepower of motor (or $\mathrm{kW}$ ).

$\mathrm{s}=$ Power-unit price;

$w=$ Labor wage rate per month in L.E.

144: Reasonable estimation of monthly average working hours.

The cost per unit of material handled " $\mathrm{Cm}$ " is estimated as follows:

$\mathrm{Cm}=\mathrm{C} /$ Actual system productivity, LE/ton, where system productivity is in "ton/h".

Where the following assumptions were made on cost elements:

\begin{tabular}{|clc|}
\hline Item & \multicolumn{1}{c}{ Description } & Value \\
$\mathrm{p}$ & Capital investment for sorting machine & $3000 \mathrm{~L} . \mathrm{E}$. \\
$\mathrm{h}$ & Yearly operating hours for sorting machine & $750 \mathrm{~h}$ \\
$\mathrm{e}$ & Life expectancy for equipment in general & 10 years \\
$\mathrm{i}$ & Interest rate & $12 \%$ \\
$\mathrm{t}$ & Taxes and overheads ratio & 0.05 \\
$\mathrm{r}$ & Maintenances and repairs ratio of the total investment & 0.1 \\
$\mathrm{P}_{\mathrm{w}}$ & Power of electric motor & $0.12 \mathrm{~kW}$ \\
$\mathrm{~s}$ & Power unit price & $0.2 \mathrm{~L} . \mathrm{E} . / \mathrm{kW} . \mathrm{h}$ \\
$\mathrm{w}$ & Labor wage rate per month & $2500 \mathrm{~L} . \mathrm{E} / \mathrm{mo}$. \\
\hline
\end{tabular}

\section{RESULTS AND DISCUSSION}

\section{1- Productivity}

was measured in manual and automatic sorting to estimate the productivity with the three types of fruits as follows:

\section{A) Manual Sorting (MS)}

MS is arranged from 22.5 to $50.1 \mathrm{~kg} / \mathrm{h}$ for tomatoes, from 27.4 to $60.1 \mathrm{~kg} / \mathrm{h}$; for apples, and from 58.4 to $134.3 \mathrm{~kg} / \mathrm{h}$ for navel oranges, as shown in Fig. (3):

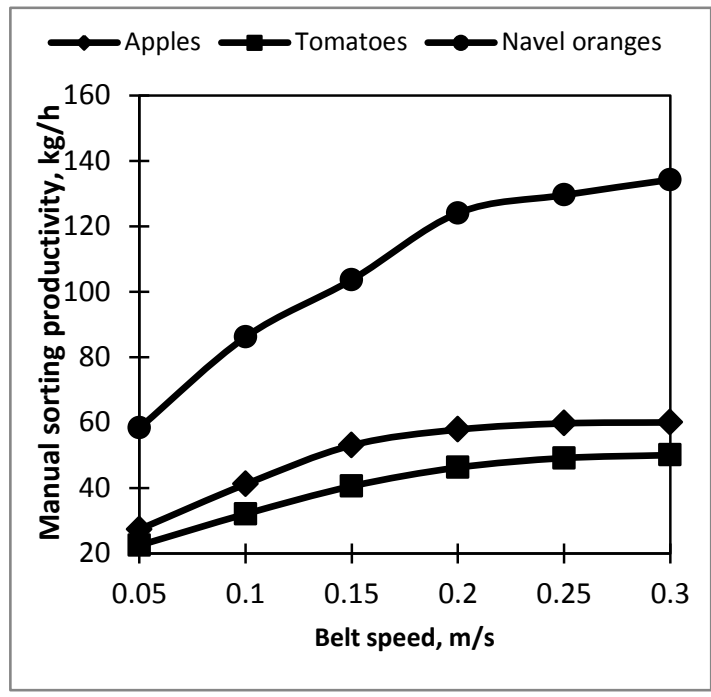

Fig. 3. Manual sorting productivity.

\section{B) Automatic Sorting Rate (ASR)}

ASR were arranged in ascending order from 25.4 to $54.8 \mathrm{~kg} / \mathrm{h}$ for tomatoes, from 30.2 to 71.5 $\mathrm{kg} / \mathrm{h}$ for apples, and from 61.2 to $142.7 \mathrm{~kg} / \mathrm{h}$ for navel oranges, as shown in Fig. (4):

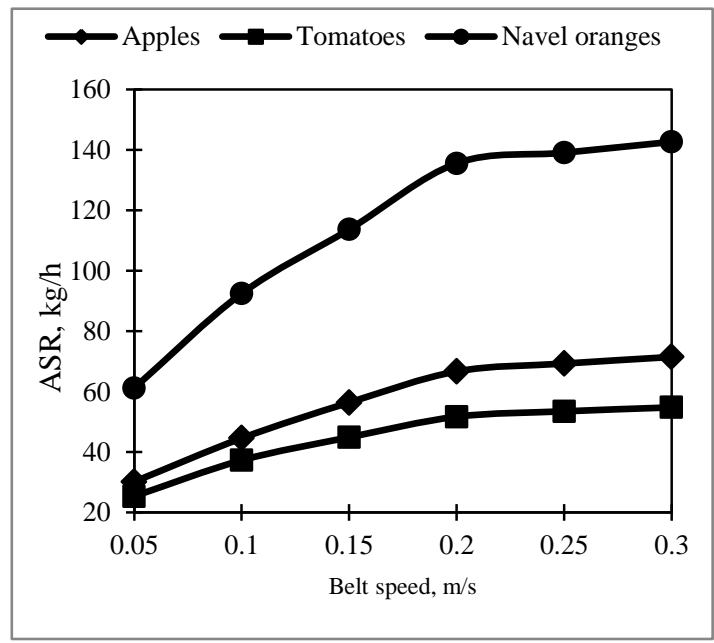

Fig. (4): Automatic sorting productivity (ASR).

\section{C) Automatic sorting error:}

It was calculated from experiments to determine the sorting machine efficiency, as shown in Fig. (5): 


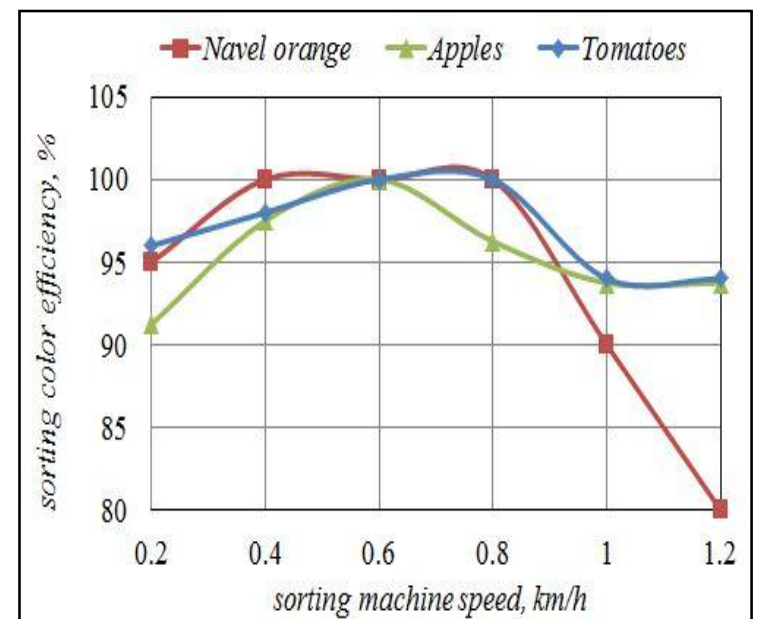

Fig. 5. Sorting system efficiency.

The efficiency of sorting was follows: tomatoes was $96 \%$ at the lowest belt speed and increased to $100 \%$ at the mean belt speed $0.8 \mathrm{~m} / \mathrm{s}$ then decreased to $94 \%$ at the highest speed, apples was $95 \%$ at the lowest belt speed and increased to $100 \%$ at the mean belt speed $0.8 \mathrm{~m} / \mathrm{s}$ then decreased to $91.25 \%$ at the highest speed, and navel orange was $95 \%$ at the lowest belt speed and increased to $100 \%$ at the mean belt speed $0.8 \mathrm{~m} / \mathrm{s}$ then decreased to $80 \%$ at the highest speed.

2- Dimensional analysis of system productivity

Groups which affect productivity of sorting with machine can be grouped by using the following relationship, Eq. 3:

$$
\frac{P_{r} T}{m}=f\left\{\frac{\mathrm{v} T \rho^{1 / 3}}{m^{1 / 3}}, \lambda\right\} \quad \text { Eq. } 3
$$

The curves below indicate that:

We can predict computer model results and curves trend from the "Matlab program" simulation by drawing the relations between $\pi$ groups as shown in the next section.

Also, we can predict the trend of curves of sorting productivity values by drawing the relations between $\pi$ groups. Also, we can approximate the machine productivity by curve fitting with groups, as shown in the following Figures (6), (7):

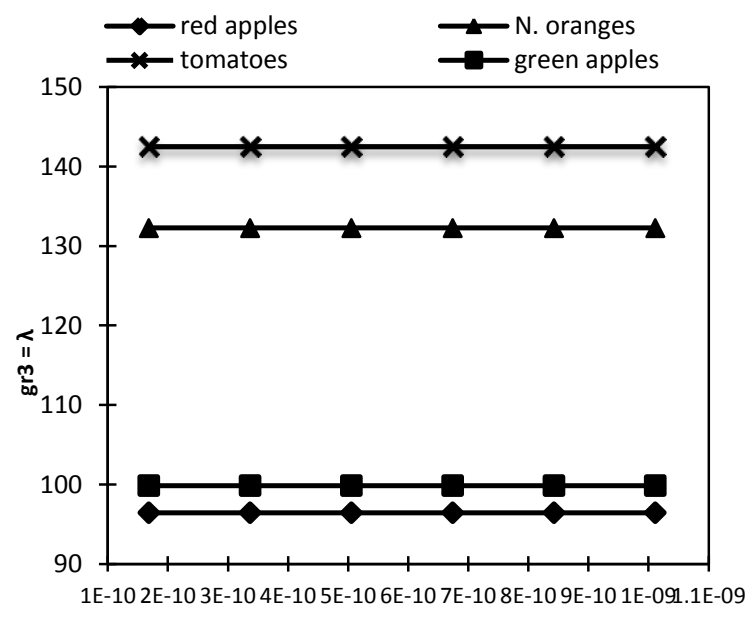

$\operatorname{gr2}=V^{*} T^{*} \rho^{\wedge} 1 / 3 / m^{\wedge} 1 / 3$

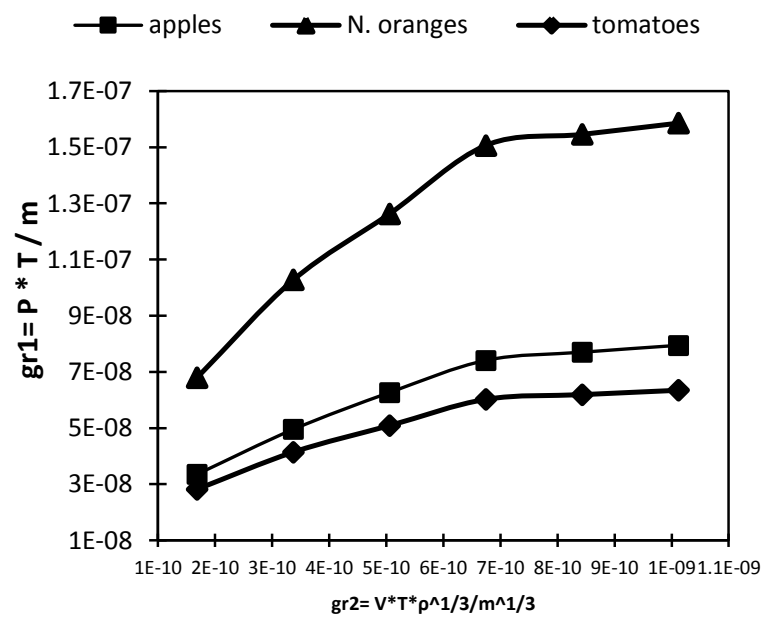

Fig. (6), (7): Pi-group relations.

\section{3- Cost analysis}

The cost of sorting process is estimated for the 2 systems:

(1) The developed machine prototype.

(2) Manual sorting for comparison.

The operation cost is estimated according to (Awady, 1978) as stated in the "Materials and Methods" section, with the relevant nomenclature.

$$
\mathrm{C}=\mathrm{p} / \mathrm{h}(1 / \mathrm{e}+\mathrm{i} / 2+\mathrm{t}+\mathrm{r})+\left(\mathrm{Pw}^{*} \mathrm{~s}\right)+\mathrm{w} / 144
$$

\section{(1) For the developed machine prototype}

Cost per hour "C" $=3000 / 750(1 / 10+0.12 / 2+0.05$ $+0.1)+(0.12 * 0.2)+800 / 144=11.89$ L.E. $/$ h. 
- Sorting machine productivity is $82.9,114.4$, and $201.2 \mathrm{~kg} / \mathrm{h}$ for tomatoes, apples, and navel orange fruits respectively.

- The cost of sorting machine per $\mathrm{kg}=$ cost per hour / productivity

$=11.89 * 1000 / 54.8=216.97$ L.E./ton for tomatoes.

$=11.89 * 1000 / 71.5=166.29$ L.E. $/$ ton for apples.

$=11.89 * 1000 / 142.7=83.32$ L.E./ton for navel orange.

\section{(2) For the manual sorting}

- Assume that the sorting operation needs one worker, with wage 800 L.E./month.

- Hence, $\quad \mathrm{C}=\mathbf{2 5 0 0} / \mathbf{1 4 4}=\mathbf{1 7 . 3 6 1 1 1}$ L.E./h.

- Capacity per man $=\mathbf{0 . 1}$ ton $/ \mathbf{h}$,

- Hence, the cost of manual sorting per ton = $17.36111 / 0.1$

= 173.6111 L.E./ton.

The sorting process cost by using the developed machine is less than the manual process in case of navel orange and apples. It could be said that, using the designed sorting machine reduced the cost of fruits sorting to 1: 2.08 as compared with manual method in navel orange sorting, and (1: 1.04) of sorting apples by designed machine. However, it was more expensive in sorting tomatoes by the developed machine compared with manual sorting by $24.97 \%$ because of the small fruits volume so the number of catching fruits will be more than apples and navel orange, thus time will increase which leads to increasing cost.

\section{CONCLUSION}

The main results in this study can be summarized in the following points:

\section{1- Productivity}

For manual sorting, RP values are arranged in ascending order from 22.5 to $50.1 \mathrm{~kg} / \mathrm{h}$ for tomatoes, from 27.4 to $60.1 \mathrm{~kg} / \mathrm{h}$ for apples, and from 58.4 to $134.3 \mathrm{~kg} / \mathrm{h}$ for navel oranges. Automatic sorting as arranged in ascending order from 25.4 to $54.8 \mathrm{~kg} / \mathrm{h}$ for tomatoes, from 30.2 to $71.5 \mathrm{~kg} / \mathrm{h}$ for apples, and from 61.2 to $142.7 \mathrm{~kg} / \mathrm{h}$ for navel oranges.

Sorting efficiency was increased to $100 \%$ with the mean system speed of $0.8 \mathrm{~m} / \mathrm{s}$ and decreased with the higher speed for the three types of fruits.

2- Dimensional analysis of the productivity system

- We can elaborate computer-model results and curve trends for the "Matlab Program" simulation by drawing the relations between $\pi$ groups, as shown in the next.

- Also, we can predict the trend of curves of sorting productivity by drawing the relation between $\pi$ groups. Thus we can approximately estimate the machine productivity values by manipulating the groups.

\section{3- Cost analysis}

The sorting process cost by using the developed machine is less than the manual process in case of navel orange and apples. It could be said that, using the developed sorting machine reduced the cost of fruits sorting to 1:2.08 as compared with manual method in navel orange, and $(1: 1.04)$ of sorting apples by the developed machine, but it was more expensive sorting tomatoes compared with manual sorting by $24.97 \%$, because of the small fruits volume. Thus the number of catching fruits will be more than apples and navel orange, and time will increase along with cost.

\section{REFERENCES}

Awady, M.N. 2013. Theory of Machines, Text Book, Fac. of Agric., Benha Univ., pp.137 159. (In Arabic).

Shen, L.J. and Hassan, I. 2015. Design and development of colour sorting robot, J. of Eng. Sci. and Tech., Spec. Issue, 1, 71 -81 


$$
\text { المؤتمر الرابع عشر لبحوث التنمية الزراعية، }
$$

\title{
تقنية الروئية الإكترونية ولستخدامها في التداول الآلي للمواد الزراعية
}

\author{
الثيماء محمل رمزي عبد الظاهر - كحملنبيل العوضي- عصام سليمان السحار \\ قسم الهندسة الززاعية- كلية الززاعة- جامعة عين شمس- ص.ب 68- حدائق شبرا
}

*Corresponding author: alshaymaamoselhy@agr.asu.edu.eg

Received 3 February, 2019, $\quad$ Accepted 17 February, 2019

تتزايد كفاءة آلة الفرز كانت حتى سرعة الآلة الوسطى

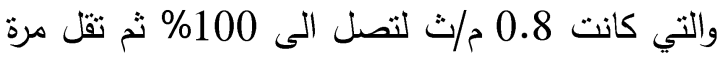

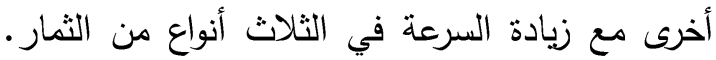
أوضحت مجموعات " " العوامل المؤثرة على عملية الفرز اللوني بإستخدام الآلة موضع الدراسة والتي يمكن التتبؤ منها بقيم الإنتاجية

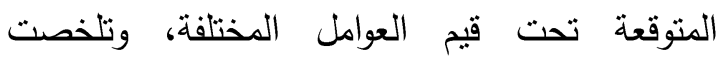

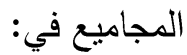

$$
\frac{P_{r} T}{m}=f\left\{\frac{v T}{(m / \rho)^{1 / 3}}, \lambda\right\}
$$

أقل تكلفة للفرز اللوني بإستخدام الآلة كانت لفرز

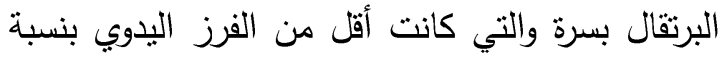
حوالي 50\%، يليها التفاح بنسبة حوالي 6 \% ب بينما كانت تكلفة الفرز اللوني للطماطم بإستخدام الآلة أعلى

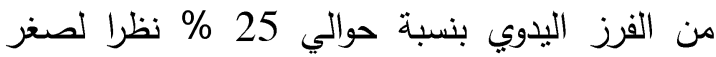
حجم الثمار والذي يستغرق وقت كبير لإجراء عملية

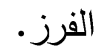

الكلمات الدالة: الروئية الإكترونية، التداول الآلي للثمار<smiles>[AlH2][AlH2]</smiles>

تم تصميم وتصنيع نموذج لآلة فرز لوني وتجربتها على 3 أنواع من المحاصيل هي الطماطح والتفاح والبرتقال أبو سرة.

ويعتمد هذا التطوير على بعض العوامل التصميمية

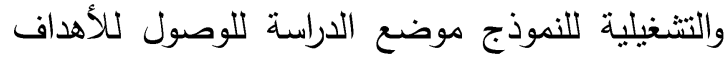

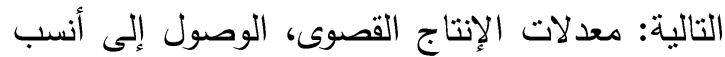

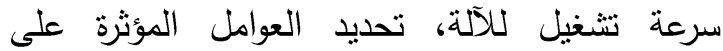
الإنتاجية.

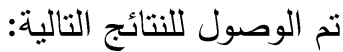

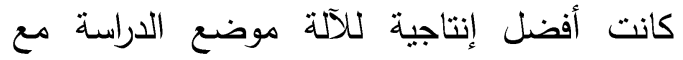

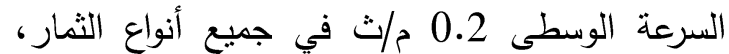

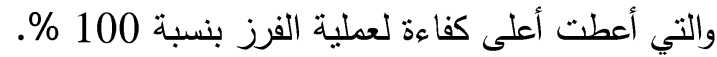
تراوحت الإنتاجية اليدوية من 22.5 إلى 50.1 كج/س في الطماطم، وتراوحت من 27.4 إلى 28.1 اللى 60.1 كج/س للتفاح، بينما تراوحت من وتراوت 58.4 إلى 134.3 كج/س للبرتقال بسرة. تراوحت إنتاجية آلة الفرز من 25.4 إلى 54.8 كج/س في الطماطم، وتراوحت من 71.5 30.2 إلى 71.5 كج/س للتفاح، بينما كانت من 61.2 إلى 142.7 كج/س اللى 14.2 